\title{
Sepsis and nursing care in pediatric patients
}

\author{
Hatice Öntürk ${ }^{a *}$ \\ a Bitlis Eren University, Health Services Vocational School, TR-13000, Bitlis Turkey
}

\section{ART I C LE INF O}

\section{Article history:}

Received 01 February 2018

Received in revised form 14 May 2018

Accepted 23 May 2018

Keywords:

Nursing care, pediatric patients, sepsis

\begin{abstract}
A B S T R A C T
Sepsis is an issue that process serious problems for years in terms of treatment and care. In addition to seen common it has always been associated with significant mortality. Sepsis is one of the frequent cases among child patients. For years, sepsis occupies the pediatric intensive care units. Treatment is very long, complicated, costly and challenging. During the treatment and care period and also during the follow-up period, it affects many systems mainly due to accompanying of other systemic problems. A good nursing care is very important in sepsis children. Sepsis requires a multidisciplinary approach.
\end{abstract}

(C) 2018. Turkish Journal Park Academic. All rights reserved.

\section{Introduction}

Sepsis is a heterogeneous clinical syndrome that may develop by any microorganisms. Sepsis cases make up a significant part of children hospitalized at Pediatric Intensive Care Units (PICU) (Köroğlu, 2008). According to World Health Organization (WHO), it is indicated that $5 \%$ of all child mortality below the age of 5 occurs due to sepsis (WHO, 2014).

Sepsis and septic shock is a frequent cause of morbidity and mortality in PICUs (Yıldızdaş, 2005). Among all children in PICUs, the prevalence of sepsis is $23 \%$ and that of septic shock is $6 \%$ (Başbakkal et al., 2015).

Whereas the causes of child mortality can be listed as congenital anomalies, prematurity, sudden infant death syndrome and sepsis until the age of 1 ; they can be listed as accidents and sepsis for the age interval of 1-14. Mortality rates due to sepsis and septic shock vary between 10-50\% for developed countries (Santschi and Leclerc, 2013).

The risk factors for sepsis are preterm borns, intensive care patients, subject to intervention (surgery, central venous catheter, urinary catheter, intubation, mechanic ventilation etc.), malnutrition, neutropenia, congenital or acquired immune deficiencies, congenital cardiac diseases, genitourinary anomaly, transplantation, burns and severe trauma (Lebel and Tapiero, 2002; Kaplan, 2003). Symptoms of sepsis may vary according to the age of the patient and the affected organs (Rahman et al., 2017; Rhodes et al., 2017).

Low body temperature, fever, sucking difficulty / intolerance, uneasiness, sleep tendency, convulsion, respiration difficulty, moaning, hepatitis (Yıldızdaş, 2005), distension, hepatosplenomegaly, vomiting, shock, change in skin color, sclerema in newborn and hemorrhage may be observed in newborns (Kaplan, 2003; Zea-Vera and Ochoa, 2015).

Similarly, in older children; symptoms related with organ dysfunctions such as heart, lung, kidney and brain, disruption in electrolyte and hormone balances, hemorrhages, hypotension, shock and coma (Kaplan, 2003).

It has been stated that nursing intervention with care guidelines applied to patients with septic shocks have affected the morbidity and mortality rates. In addition, a large number of studies have shown that care and treatment in the direction of developed guidelines reduces the length of hospital stay (Huang et al., 2016; Başbakkal et al., 2015).

It should not be forgotten that and early diagnosis, early fluid therapy and professional nursing care and initiatives with raising awareness of sepsis are very important in preventing

\footnotetext{
* Corresponding author.

Tel.: +0 434222 0094-9401

E-mail address: honturk@beu.edu.tr
} 
sepsis development and successful treatment (Huang et al., 2016).

\section{Treatment}

Initial empirical treatment is planned according to the focal infection point, age group of the patient, risk factor, the microorganism profile of the region and the hospital and antibiotic resistance (Kerste, 2016). Wide spectrum antibiotics and frequently combination treatment should be applied taking into consideration the microorganisms with multiple resistances that develop in sepsis and septic shock in patients that have previously undergone antibiotic treatment. Ampicillin + aminoglycoside or 3rd generation cephalosporin + aminoglycoside treatment combinations are suggested in newborn early sepsis (Rahman et al., 2017).

- Cefotaxime or ceftriaxone is sufficient for the treatment of sepsis due to community after the newborn period

- If sepsis is accompanied by meningitis formed due to a gram positive microorganism or one with unknown etiology, combination treatment should be provided (Yıldızdaş, 2005).

The vasodilator effect medications used in septic shock treatment are phosphodiesterase inhibitors, nitroprusside and nitroglycerine. The half-lives of nitroprusside and nitroglycerine are very short and their effects immediately disappear when infusion is stopped. Vasodilator medications are used on patients with continuing shock and normal blood pressure despite the use of dopamine and epinephrine (Sparrow and Willis, 2003).

Medications with inotrope effect, vasodilator medications, steroids, hematologic medications (Çıtak, 2012).

Central catheter should be placed for vasoactive medications (Delinger et al., 2012). Crystalloids are suggested for the initial fluid resuscitation in fluid treatment. It is suggested to add colloid to initial fluid resuscitation. Crystalloids should be $10-20 \mathrm{ml} / \mathrm{kg}$ and fluid loading should be completed at most in 5 minutes. The patient should be monitored for fluid loading symptoms (raller, hepatomegalia etc.). Mortality in children occurs due to severe hypovolemia and low cardiac out-put. Every hour that passes before starting fluid treatment doubles the mortality rate. At first, $500-1000 \mathrm{ml}$ crystalloid or 300$500 \mathrm{ml}$ colloid infusion is suggested during the first 30 minutes (Düzkaya et al., 2013).

At least 2 blood culture samples (0.5-2 ml) should be taken prior to antibiotic treatment. Skin cleansing should be carried out using alcohol when drawing blood culture sample. Wide spectrum antibiotic treatment should be started within an hour.

\section{Nursing Approaches}

The nurse constantly monitors the diagnosis and treatment of any patient. For this reason, nursing care and approaches are factors that directly affect patient satisfaction. Synergy of patient and nurse has an important place in raising patient satisfaction. In this study, nursing approaches for sepsis will be treated nursing diagnoses and nursing care. Suggestions will be made in light of this information given.

\subsection{Nursing Diagnoses}

- Ineffective respiration due to septic shock advancement and rapid respiration

- Decrease in cardiac output, insufficient tissue perfusion due to hypotension and severe vasodilatation

- Decrease in cardiac output due to hypovolemia, peripheral vasodilatation and myocardial insufficiency

- $\quad$ Fluid electrolyte imbalance due to nausea, vomiting, diarrhea, high fever

- Deterioration in oral mucosa membranes

- Decrease in tissue perfusion and hypothermia due to slowness in metabolism

- Infection risk due to trauma or invasive treatment applications

- Transfer to intensive care, existence of life threatening condition and anxiety that develops due to bad feelings about the regression of the disease

- Lack of coping of the family due to the uncertainty of the patient status (Carpenito, 2012).

\subsection{Nursing Care}

- The first hour in the treatment and care of a patient with septic shock is the resuscitations stage.

- Pulse oximeter, EKG monitor, blood pressure, fever monitoring, urinary output, glycose and ionized calcium levels, lactate level are continuously monitored during this stage (Düzkaya et al., 2013).

- Ensuring airway patency and its continuity are the first steps that should be carried out in sepsis.

- Decisions are given for changing the position of the patient in order to attain airway patency, use of airway and application of intubation for patients without spontaneous respiration (Delinger et al., 2012; Çelebi, 2006).

- $\quad$ Fluid treatment is essential in initial resuscitation. At least two vascular accesses should be opened during vascular evaluation and intraosseous should be preferred if peripheral vascular access cannot be opened. 


\subsection{Suggestions}

- It is suggested to monitor the patients very well,

- Change their positions frequently,

- Wash hands prior to and after the operation, use gloves continuously,

- Ensure patient isolation,

- Follow the aseptic technique when using tools,

- Provide required training to all staff members,

- Use of effective disinfectant and antiseptics inside the unit,

- Develop understandable and easy to use guides and place them at unit entrance and on important locations.

\section{Results}

Nursing profession is a kind of profession that comes to the forefront in terms of all stages of any illness and patient satisfaction. The knowledge and experience of the nurse is one of the factors that prevent the negativity that can be seen in the patient. This is even more important if the patient is a child. In this study, information is given about sepsis and nursing care in pediatric patients. In this study, recommendations for treatment, nursing diagnoses and care to be applied to such patients are made. Sepsis in pediatric patients can be prevented by these methods.

\section{References}

Başbakkal, and Kahraman, 2015. Nursing approach in pediatric sepsis and septic shock. case report. Turkiye Klinikleri Journal of Nursing Sciences, 8(2), 172-186.

Carpenito, L.J., 2012. Hemșirelik Tanıları El Kitabı. Çeviren Erdemir F. Nobel Tip. Türkiye

Çelebi, S., 2006. Çocuklarda Sepsis ve Septik Şok. Journal of Current Pediatri, 4.

Çıtak, A., 2012. Çocukluk yaş grubunda şok ve tedavisi. Çocuk Dergisi. 12(3), 99-112.

Dellinger, R.P., Levy, M.M., Rhodes, A., Annane, D., Gerlach, H., Opal, S.M., 2013. Surviving sepsis campaign: international guidelines for management of severe sepsis and septic shock. Critical Care Medicine, 41(2), 580-637.

Düzkaya, D.S., Bozkurt, G., 2013. Çocuklarda sepsis ve hemşirelik bakımı. Yoğun Bakım Hemşireliği Dergisi, 17(1), 21-28.
Huang, F.K., Chen, H.L., Yang, P.H., Lin, H.C., 2016. Bird's eye view of a neonatologist: clinical approach to emergency neonatal infection. Pediatrics and Neonatology, 57(3), 167-73.

http://www.who.int/gho/child_health/mortality/causes/en/index,2 010. (Date of access: 25.11.2014).

http://www.who.int/gho/child_health/mortality/causes/en/index.ht $\mathrm{ml}$ (Date of access: 25.11.2014.).

Kaplan, S., 2003. Bacteremia and septic shock. In: Long SL, Pickering LK, Prober GC (eds). Principles and Practice of Pediatric Infectious Disease, 2nd edition. New York, Churchill Livingstone; 810-25.

Kerste, M., Corver. J., Sonnevelt, M.C., Van Brakel, M., Van Der Linden, P.D., M., Braams-Lisman, B.A., Plötz, F.B., 2016. Application of sepsis calculator in newborns with suspected infection. The Journal of Maternal-Fetal \& Neonatal Medicine, 29(23), 3860-3865.

Köroğlu, T.F., 2008. Sepsis ve Septik Şok. Metin Karaböcüoğlu, Tolga F. Köroğlu. (Eds.) Çocuk Yoğun Bakım Esaslar ve Uygulamalar. İstanbul: Medikal Yayıncllık. Türkiye; 753-763.

Lebel, M., Tapiero, B., 2002. Bacteremia, Sepsis and Septic Shock. In: Jenson HB, Baltimore RS (eds). Pediatric Infectious Diseases, 2nd edition. Philadelphia: WB Saunders Company; 279-95.

Rahman, A.E., Iqbal, A., Hoque, D.M.E., Moinuddin, M., Zaman, S.B., Rahman, Q.S., et al., 2017. Managing neonatal and early childhood syndromic sepsis in sub-district hospitals in resource poor settings: improvement in quality of care through introduction of a package of interventions in rural Bangladesh. PLoS ONE 12(1): e0170267.

Andrew Rhodes., Ç., Laura, E., Evans Waleed, Alhazzani, Mitchell M., Levy Massimo Antonelli Ricard Ferrer Anand Kumar Jonathan E. Sevransky Charles L. Sprung Mark E. Nunnally Bram Rochwerg Gordon, D., Rubenfeld Derek, C., Angus Djillali Annane Richard, J., 2017. Beale surviving sepsis campaign: international guidelines for management of sepsis and septic shock 2016. Intensive Care Medicine. 43(3), 304-377.

Santschi, M., Leclerc, F., 2013. Management of children with sepsis and septic shock: a survey among pediatric intensivists of the Réseau Mère-Enfant de la Francophonie. Annals of Intensive Care. 3:7.

Sparrow, A., Willis, F., 2004. Management of septic shock in childhood. Emergency Medicine Australasia, 16(2), 125-134.

Yıldızdaş, D., Yapıcıoğlu, H., Tümgör, G., Erbey, F., 2005. Çocuk yoğun bakım ünitesinde sepsis nedeni ile izlenen hastalarda poliklonal intravenöz immünglobülin tedavisi mortaliteyi azaltıyor mu? Çocuk Sağlığı ve Hastalıkları Dergisi. 48, 136-141.

Zea-Vera, A., Ochoa, T.J., 2015. Challenges in the diagnosis and management of neonatal sepsis. Journal of Tropical Pediatrics, 61(1), $1-13$. 